\title{
VIA ACTIVA A VIA CONTEMPLATIVA VO VYBRANÝCH INTERPRETÁCIÁCH RENESANČNÝCH DIEL ERWINOM PANOFSKYM
}

\author{
STANISLAVA KUSTROVÁ \\ Katedra dejín a teórie umenia, Filozofická fakulta Trnavskej univerzity v Trnave \\ E-mail: kustrova.s@gmail.com
}

\begin{abstract}
Via Activa and Via Contemplativa in Selected Interpretations of Renaissance Artworks by Erwin Panofsky

The paper deals with the processing of the theme of active and contemplative life in three selected examples of Renaissance art, namely in Dürer's engravings Knight, Death and the Devil and Saint Jerome in His Study and Titian's painting Sacred and Profane Love. These three artworks were also interpreted by Erwin Panofsky. According to the Panofsky's interpretations, the ideals of active and contemplative life in the three mentioned artworks are rendered as two mutually contrasting and incompatible ideals. After a brief introduction into the Renaissance Neo-platonic teachings on an active and contemplative life, which was also used by Panofsky in his interpretations, the paper points out that ideals of activity and contemplation depicted in the two Dürer's engravings and in the Titian's painting can also be interpreted as complementary and mutually penetrating ideals. Moreover, the paper points to the possibility that Erwin Panofsky was influenced by his own understanding of the subject in the perception and interpretation of the three artworks.
\end{abstract}

Keywords: active life; contemplative life; Dürer; Titian; Panofsky; Ficino; neoplatonism

Dve rytiny Albrechta Dürera a to Rytier, smrt' a diabol (1513) a Sv. Hieronym vo svojej pracovni (1514) a Tizianova malba Láska nebeská, láska pozemská (1515) predstavujú tri diela, ktoré budú východiskom pri mojich úvahách. Tieto diela interpretoval okrem iných historikov umenia aj Erwin Panofsky (1892-1968). Podla Panofského interpretácií predstavujú uvedené dve Dürerove rytiny a Tizianova malba špecifické spracovanie problematiky via activa a via contemplativa, ako ju vnímali konkrétni predstavitelia renesančného novoplatonizmu. Kým Dürer mal podla Panofského pri zhotovovaní svojich troch „majstrovských rytín“, medzi ktoré popri Melanchólii I patrí aj Rytier, smrt a diabol a Sv. Hieronym vo svojej pracovni, obsahovo čerpat z textu Cornelia Agrippu z Nettesheimu O okultnej filozofii, ktorý je odvodený z Troch kníh o živote spísaných novoplatonikom Marsiliom Ficinom, ${ }^{1}$ Tizian mal pri tvorbe Lásky nebeskej, lásky pozemskej vychádzat z náuky o láske rozpracovanej Marsiliom Ficinom v spise $O$ láske. ${ }^{2}$

Po krátkom predstavení Panofského interpretácií vybraných troch umeleckých diel a novoplatónskej náuky týkajúcej sa problematiky via activa a via contemplativa sa za-

Erwin Panofsky, The Life and Art of Albrecht Dürer, Princeton 2005, s. 169.

2 Erwin Panofsky, Studies In Iconology. Humanistic Themes In The Art Of The Renaissance, New York 1972, s. 146-150. Tizian mal čerpat konkrétne z diela Pietra Bemba Asolani, ktoré je pretransformovanou verziou Ficinovho spisu O láske. 
meriam aj na Panofského vlastné názory na aktívny a kontemplatívny spôsob života. V závere sa budem zamýšlat nad tým, či a ako mohlo Panofského vlastné chápanie danej problematiky ovplyvnit jeho percepciu a interpretáciu uvedených diel.

Rytina Rytier, smrt’ a diabol [Obr. 1] podla Panofského výkladu „reprezentuje život krestana $v$ praktickom svete rozhodovania sa a akcie“.3 Ako sa v Panofského interpretácii dalej uvádza, táto Dürerova rytina mala byt’ ovplyvnená textom Príručka krestanského vojaka (1501) od Erazma Rotterdamského. Podla Erazmovej rady krestanský vojak najlepšie porazí svojich nepriatelov tým, že ich bude ignorovat’ a pokladat za fantómov, za nič. Panofsky tvrdí, že práve tento moment je na Dürerovej rytine zachytený - vidíme vojaka cválajúceho pevne a pokojne vpred nevšímajúc si svojich nepriatelov.

Druhá z dvoch Dürerových rytín, Sv. Hieronym vo svojej pracovni [Obr. 2], má reprezentovat' „život svätca v duchovnom svete posvätnej kontemplácie“. ${ }^{4}$ Panofsky pri interpretovaní diela zdôrazňuje pokojné ústranie svätcovej cely a príjemnú atmosféru celkového výjavu. To, že sv. Hieronym je umiestnený v zadnej časti cely a je strážený zvieratami zobrazenými v prednom pláne kompozície, má zdôraznit’ svätcovu neprístupnost’ a nemožnost' jeho vyrušenia $\mathrm{z}$ kontemplatívnej aktivity.

V kontexte troch Dürerových „majstrovských rytín“ Panofsky - vychádzajúc z textu O okultnej filozofii - interpretuje postavu z rytiny Melanchólia I ako obraz bytosti s prevládajúcou imagináciou, zatial čo rytier má predstavovat človeka, ktorý vdaka dominantnému pôsobeniu rozumu vedie racionálny a praktický spôsob života a napokon sv. Hieronym má zosobňovat’ človeka, ktorého prevažujúca kontemplatívna mysel sa povznáša do stavu nazerania. ${ }^{5}$

Kým v predchádzajúcich dvoch Dürerových rytinách boli podla Panofského výkladu ideály aktívneho a kontemplatívneho života stvárnené separovane, v prípade Tizianovej Lásky nebeskej, lásky pozemskej [Obr. 3] majú byt’ oba ideály prítomné v rámci jednej kompozície. Panofsky tvrdí, že v Láske nebeskej, láske pozemskej je vyjadrený „kontrast medzi vznešeným a menej ušlachtilým princípom" “6 Kým obnažená postava ženy, Nebeská Venuša, symbolizuje čisto inteligibilnú krásu a zároveň kontemplatívnu aktivitu, odetá žena, Pozemská Venuša, zastupuje zmyslami vnímatelnú krásu a tiež aktívny princíp, generačnú silu, ktorá tvorí formy dobra a krásy na zemi. ${ }^{7}$

Ako už bolo poznamenané, podla Erwina Panofského majú byt’ dve Dürerove rytiny a Tizianova mal'ba odlišnými variáciami na tému aktívneho a kontemplatívneho života, ako ju vo svojich spisoch rozpracoval Marsilio Ficino a ako ju pretransformovali jeho nasledovníci. Ficino vo svojich textoch pracuje s obrazmi planetárnych božstiev, pričom im prisudzuje charakteristické vlastnosti a vplyvy, a určuje ich špecifické miesto pôsobnosti v človeku. Vo svojom texte zaoberajúcom sa novoplatónskym hnutím vo Florencii Panofsky vychádzajúc z Ficinovej náuky vysvetluje: „Bud' ludský rozum [...] môže byt' využitý na úlohu zdokonalovania ludského života a údelu na zemi, alebo jeho mysel' môže priamo prenikat rísu večnej pravdy a krásy. V prvom prípade praktizuje morálne cnosti tvorené pod

\footnotetext{
Panofsky (pozn. 1), s. 151.

Ibidem, s. 151.

Ibidem, s. 169-170. - Heinrich Cornelius Agrippa von Nettesheim, Three Books of Occult Philosophy, St. Paul 2004, s. 188-192.

Panofsky (pozn. 2), s. 150.

Ibidem, s. 150-153.
} 
vedením spravodlivosti a tým sa rozoznáva v aktívnom živote [...] a kozmologicky sa pripája $k$ Jupiterovi. V druhom prípade pridáva $k$ morálnym cnostiam teologické a zasväcuje sa kontemplatívnemu životu [...] a podrobuje sa poručníctvu Saturna. "8 Ak má teda v človeku dominantnú pozíciu rozum, takýto človek sa prikláňa k aktívnemu spôsobu života a kozmologicky je spätý s Jupiterom. Ak však v človeku prevažuje činnost’ mysle, človek je prirodzene pritahovaný ku kontemplácii a vztahuje sa k Saturnovi.

Podla Panofského tvrdenia bol Ficino „omnoho radikálnejší v obhajovaní spôsobu via contemplativa“.9 V kontexte Ficinovej novoplatónskej filozofie, v rámci ktorej Saturn zastupuje mysel’ ako najvyššiu oblast' ludskej duše, by sa dalo očakávat', že táto najvyššia z planét bude Ficinom predstavovaná ako ciel' všetkých, ktorí sa vydali vzostupnou platónskou cestou a Jupiter, planetárny boh operujúci v rozume a patrón aktívneho spôsobu života, zas bude vnímaný ako menej hodnotná inštancia. Avšak pri štúdiu Ficinovho diela Tri knihy o živote sa možno stretnút' s viacerými prekvapivými tvrdeniami.

Marsilio Ficino vo svojej tretej z Troch kníh o živote jasne deklaruje, že Jupiter vládne aktívnemu spôsobu života, kým Saturn je pánom nad životom kontemplatívnym. ${ }^{10}$ Avšak v jeho úvahách o planétach, ktorých vplyv je pre človeka najprospešnejší, nenájdeme ani zmienku o Saturnovi. Miesto jediného Saturna Ficino hovorí o takzvaných Troch Gráciách - o troch planétach, ktoré sú pre človeka najužitočnejšie. Týmito planétami sú Slnko, Jupiter a Venuša. Ficino človeku neodporúča, aby sa vložil do starostlivosti iba jedného božstva, ale má prijímat čo najväčšie množstvo priaznivých planetárnych vplyvov. Píše: „Ak by ta nevyhnutnost alebo povinnost nútili k obráteniu sa len na jedného $z$ týchto velikánov, uchýl'sa $k$ samotnému Jupiterovi, nakol'ko žiadna hviezda nepodporuje a neživí prirodzené sily v nás - vlastne všetky sily - viac než Jupiter, ani žiadna iná hviezda neponúkne viac vecí alebo viac prospešnejších vecí. "11 Je to práve Jupiter, ktorý je Ficinom vyzdvihovaný väčšmi než Saturn. Jupiter v sebe v najlepšej a najvyváženejšej miere pre človeka združuje vlastnosti viacerých planét. Ak človek oplýva joviálnou povahou, bude vynikat’ nie len aktívnym zapájaním sa do občianskeho života, úctou k zákonom, absenciou životnej strnulosti či lenivosti, ale bude tiež príznačný svojou harmonickostou a umiernenostou a zároveň potrebnou vášnivostou, zanietením a pod. A čo je dôležité, joviálny duch podla Ficina nesie podobnost' aj so samotným Saturnom, čo vyplýva z jeho nasledovného tvrdenia: „Jupiter je taktiež užitočný pre filozofiu a odhalovanie pravdy a pre náboženstvo."12

Proti očakávaniu vyplývajúcemu z Panofského tvrdenia o Ficinovom radikálnom „obhajovaní spôsobu via contemplativa"13 je Saturn na mnohých miestach Troch kníh $o$ živote predstavovaný ako neblahý zdroj negatívnych vlastností a vplyvov a taktiež ako jav, ktorému by sa mal človek v čo najväčšej možnej miere vyhýbat'. O Saturnovi sa dozve-

8 Ibidem, s. 138. Podla Ficinovej náuky sa duša človeka skladá z vyššej a nižšej časti, pričom vyššia čast je sídlom mysle a rozumu, kým nižšia čast’ v sebe zahŕňa oblast rozmnožovania, výživy a rastu a oblasti vonkajšieho a vnútorného vnímania. Ibidem, s. 136. - Erwin Panofsky, Renaissance and Renascences in Western Art, Boulder 1960, s. 183.

9 Panofsky (pozn. 2), s. 140.

10 Marsilio Ficino, Three Books on Life, Tempe 1998, s. 253.

11 Ibidem, s. 269.

12 Ibidem, s. 265.

13 Panofsky (pozn. 2), s. 140. 
dáme nasledovné: „Zdravý duch nemá vela spoločného so Saturnom." ${ }^{14}$, „Nakolko Slnko vychádza v ústrety [ludskému] pokoleniu, natolko je preň Saturn nevhodný. "15 alebo inde: „Jeho vplyv je ako jed. Kvôli takémuto [vplyvu] sa niektorí ludia rodia alebo sa stávajú nečistými, lenivými, smutnými, závistlivými a vystavenými nečistým démonom. [...] Proti tomuto jeho vplyvu, ktorý je vo všeobecnosti cudzi a istým spôsobom škodlivý ludskému bytiu, nás vyzbrojuje Jupiter. "16 Teda Saturn, zástupca a patrón mysle a kontemplatívnej aktivity, je Ficinom predstavovaný ako jed škodiaci ludskej bytosti. ${ }^{17}$

Ako je vôbec možné, že tento Saturn bol v rámci novoplatónskej filozofie vyvyšovaný ako patrón via contemplativa a to $\mathrm{v}$ plne pozitívnom zmysle? Saturn je špecifická postava príznačná svojou dichotomickou povahou. Vo svojom pôsobení na ludí je Saturn akoby rozpoltený. Ficino píše: „Saturn jednoducho nemôže značit’ nejakú všeobecnú kvalitu a neoznačuje ani vel'ké množstvo ludskej rasy, [...] značí jednotlivca božského alebo zverského, požehnaného alebo utrápeného extrémnou mizériou. "18 Tam, kde Jupiter predstavuje jedinú zlatú strednú cestu, je Saturn dvomi protikladnými pólmi - človek môže žit pod vedením Saturna bud' ako boh, alebo ako zviera, jeho život môže značit' bud' požehnanie a úspech, alebo extrémnu zúfalost'. Saturnovými vyvolencami sú podla Ficina práve tí, ktorí sa bezvýhradne odovzdali jeho vplyvu a to bez nároku na pôsobenie iných planetárnych božstiev. Sú to jedinci, v ktorých absolútne prevažuje kontemplatívna mysel. ${ }^{19}$

Ficino napriek tomu, že priamo označuje dominanciu Saturnovho pôsobenia v kontemplatívnej oblasti a napriek tomu, že uznáva možnost' pozitívneho vplyvu Saturna na človeka, predsa odporúča, aby si ludský jedinec pre svoj život zvolil radšej vplyv Jupitera, ktorý je podla jeho tvrdenia „človeku najvyhovujúcejši““20 Ak sa však človek predsa vloží pod patronát Saturna, má zmierňovat’ saturninský vplyv inými planetárnymi a to zvlášt joviálnymi vplyvmi.

Vrátme sa opät k vizuálnym spodobeniam z úvodu príspevku. Panofsky pri interpretácii dvoch Dürerových rytín uvádza: „Sv. Hieronym sa odlišuje od Rytiera, smrti a diabla tak, ako ideál via contemplativa odporuje ideálu via activa."21 S Panofského tvrdením o dvoch vzájomne si odporujúcich ideáloch možno polemizovat'. Už pri zbežnom zapozeraní sa na uvedené rytiny možno vnímat', ako sa $\mathrm{v}$ oboch z nich ideály via activa a via contemplativa navzájom prenikajú a doplňajú. Dürerov rytier Panofskym predstavený ako ideál aktívneho spôsobu života nie je zobrazený ako fyzicky činný bojovník, ktorý pomocou svojej výzbroje poráža prítomných nepriatelov, naopak, je spodobený ako muž mimoriadne pokojný až pasívny. Vychádzajúc z Panofského výkladu môžeme v rytierovi vidiet človeka, ktorý bol v kontemplácii poučený Erazmovými radami týkajúcimi sa morálnych hodnôt a ktorý takto poučený napreduje neútočiac a pokojne vpred ignorujúc svojich nepriatelov. Na druhej strane sa sv. Hieronym, ideál kontemplatívneho života, javí

\footnotetext{
Ficino (pozn. 10), s. 293.

Ibidem, s. 345.

Ibidem, s. 367.

7 Ficino na „Saturnov jed“ ponúka hned’ niekolko liekov v podobe vplyvu iných planét. Okrem Jupitera možno zvolit’ na oslabenie Saturnovho neblahého účinku i Venušu, Slnko či Mesiac s ich vlastnými účinkami. Ibidem, s. 263-269.

8 Ibidem, s. 251.

19 Ibidem, 365-367.

20 Ibidem, s. 269.

21 Panofsky (pozn. 1), s. 156.
} 
byt’ v porovnaní s rytierom mimoriadne aktívny. Svätec, ktorého by sme si ako zástupcu via contemplativa vedeli predstavit’ skôr pohrúženého v úvahách s lebkou v ruke, sa v plnom sústredení skláňa nad knihou, do ktorej niečo horlivo zapisuje. Sv. Hieronym je na Dürerovej rytine zobrazený ako ten, ktorý má svojím spisovatel'ským a prekladatel’ským dielom poslúžit’ spoločnosti, pričom obsah jeho kníh má byt’ usmernením nie len pre kontemplatívnu, ale zvlášt pre spoločensky činnú aktivitu človeka. Dve Dürerove rytiny predstavujú hlboký paradox, $\mathrm{v}$ rámci ktorého možno pozorovat pasívneho rytiera ako obraz aktívneho života a aktívneho svätca ako obraz života kontemplatívneho.

Podobne Tizianova kompozícia Láska nebeská, láska pozemská by mohla byt’ interpretovaná ako spodobenie dvoch aktivít prítomných v jednom človeku. Panofsky vysvetluje dve postavy na obraze ako dva princípy, ktoré sú síce oba hodnotné, no navzájom sa vylučujú. O postave Nebeskej Venuše píše, že „s jemne presviedčajúcim pohladom odovzdáva [Pozemskej Venuši] tajomstvá z vyššej oblasti“22 a takto sa ju akoby snaží priviest' z oblasti aktívnej do oblasti kontemplatívnej. Avšak vychádzajúc z Ficinovho textu O láske, z ktorého pri interpretácii vychádzal i Panofsky, sa dá pohlad Nebeskej Venuše rovnako dobre interpretovat' aj ako zamilovaný pohlad mysle, ktorá - bez akéhokolvek presviedčania - kontempluje krásu prítomnú v nižších častiach duše. ${ }^{23} \mathrm{~V}$ plne sústredenom a rozpálenom pohlade Nebeskej Venuše zastupujúcej kontemplujúcu mysel' môže byt prítomná skôr úcta i rešpekt voči prospešným činným aktivitám človeka.

Vyvstáva otázka, prečo Erwin Panofsky vo svojich interpretáciách uvedených diel nepočíta s možnostou striedania spoločensky činných a kontemplatívnych aktivít v živote človeka a to napriek tomu, že Marsilio Ficino, z ktorého náuky Panofsky pri interpretáciách hojne čerpal, odporúča kombinovanie aktívnych a kontemplatívnych spôsobov ako prostriedok na udržanie zdravého života a myslenia. ${ }^{24}$ Panofsky predkladá koncepty via activa a via contemplativa ako striktne oddelené, odporujúce si či nesúčinné, pričom ideál kontemplatívneho života podčiarkoval ako hodnotovo a kvalitatívne nadradený. Panofsky síce mohol svoje tvrdenia podopriet’ novoplatónskym učením, no je tiež možné, že jeho percepcia a interpretácia diel vyobrazujúcich princípy via activa a via contemplativa bola ovplyvnená jeho vlastným vnímaním danej problematiky.

Vo svojom texte Na obranu veže zo slonovej kosti ${ }^{25}$ Panofsky porovnáva aktívny a kontemplatívny život a možnosti i obmedzenia ludí, ktorí sú činní v rámci jednej z týchto dvoch životných ciest. Panofsky priznáva „mužovi praxe“ a „samotárskemu myslitelovi“, ktorého vo svojom texte umiestňuje do veže zo slonovej kosti, jasne protikladné postavenie. Píše: „Muž na zemi má možnost’ jednat', ale nevidí [...]. Muž na veži vidí, ale nemá možnost' jednat. " 26 Muž vo veži má vd’aka širšiemu rozhladu potenciál skôr si všimnút

22 Panofsky (pozn. 2), s. 152.

23 Ficino v diele O láske píše: „Ked’sa náš pohlad prvýkrát stretne s krásou ludského tela, mysel,' ktorá je prvou Venušou v nás, chváli a adoruje ludskú krásu ako obraz božskej krásy a takýmto spôsobom je prvá [Venuša] často rozpálená druhou [Venušou].“ Marsilio Ficino - Sears Reynolds Jayne, Marsilio Ficino's Commentary on Plato's Symposium: the text and a translation, with an introduction, Columbia 1944, s. 143.

24 Ficino vnímal ako vel'kú hrozbu životnú strnulost' a nemennost', ktoré pripisoval práve pôsobeniu Saturna. Zdravým prostredím pre správny rozvoj človeka je práve rozmanité no zároveň dobre vyvážené prostredie. V Tretej knihe o żivote sa píše: „Rozmanitost chráni pred nudou, ktorá je duchom škodlivá a patrí k Saturnovi." Ficino (pozn. 10), s. 293.

25 Erwin Panofsky, Význam ve výtvarném umění, Praha 2013, s. 361-373.

26 Ibidem, s. 370. 
hroziace nebezpečenstvo, no zároveň má i povinnost’ pozdvihnút svoj hlas a upozornit’ ludí mimo veže na blížiacu sa pohromu. Potom je už na mužoch činných na zemi, aby sa započúvali do varujúceho hlasu myslitela a vyvinuli potrebnú aktivitu na odvrátenie nebezpečenstva.

Napriek uznaniu skvelých výsledkov, ktoré možno pri spolupráci ludských kontemplatívnych a činných aktivít dosiahnut', Panofsky zastáva názor, podla ktorého by mal človek zostat verný svojmu povolaniu bud' k životu aktívnemu, alebo k životu kontemplatívnemu. V jeho texte Na obranu veže zo slonovej kosti nenájdeme ani zmienku o kombinovaní či zamieňaní uvedených činností v živote človeka. Panofsky zdôrazňuje, že i napriek všetkým výčitkám zo strany ludí činných na zemi môžu „obyvatelia veže kludne zostat' tam, kde sứ ${ }^{\prime 27}$ a svoj text uzatvára nasledovne: „Strážca môže jedine volat na poplach. Aby však mohol plnit’ aspoň túto vel'kú úlohu, musí zostat'verný svojej veži." ${ }^{28}$

Vychádzajúc z Panofského tvrdení by sme mohli konštatovat', že myslitel na seba nemôže prebrat aktivitu muža praxe a muž praxe aktivitu myslitela. Avšak na celú problematiku sa možno pozriet’ aj inak. Podobne ako pri Dürerových rytinách a Tizianovej mal'be aj tu možno vnímat’ súčinnost' ludskej kontemplatívnej a činnej aktivity. Ak chcú myslitelia ludí varovat', musia prekročit prah tichého uvažovania, musia vniknút do spoločenstva aktívne žijúcich ludí a vyvinút medzi nimi výraznú aktivitu v podobe vysvetlovania či volania. Na druhej strane, ak chcú ludia uskutočňujúci aktívny život počut a počúvnut' ludí kontemplujúcich, musia sa vo svojich činných aktivitách zastavit’ a uvažovat’ nad obsahom toho, čo im kontemplujúci zdielajú, aby následne dokázali vyvinút správnu a prospešnú aktivitu. V takejto situácii možno vnímat', ako vyvinutá činná aktivita kontemplujúcich vtahuje činne aktívnych do kontemplácie. Nastáva moment, kedy si aktívni a kontemplujúci vymieňajú svoje role a v tomto dôležitom momente prieniku via activa a via contemplativa sa môže svet skutočne udržiavat', zvelad’ovat' a dokonca zachraňovat'.

\section{LITERATÚRA}

Heinrich Cornelius Agrippa von Nettesheim, Three Books of Occult Philosophy, St. Paul 2004.

Michael J. B. Allen, Marsilio Ficino: his theology, his philosophy, his legacy, Leiden - Boston - Köln 2002.

Giulia Bartrum et al., Albrecht Dürer and his legacy: the graphic work of a renaissance artist, London 2003 (2. vydání).

Andrea Bayer (ed.), Art and love in Renaissance Italy, New York 2008.

Heiner Borggrefe, Tizians sogenannte Himmlische und Irdische Liebe: Der Beistand der Venus im Hochzeitsbild der Laura Bagarotto, Zeitschrift für Kunstgeschichte LXIV, 2001, č. 3, s. 331-363.

Melissa Meriam Bullard, The Inward Zodiac: A Development in Ficino's Thought on Astrology, Renaissance Quarterly XLIII, 1990, č. 4, s. 687-708.

Eugene B. Cantelupe, Titian's Sacred and Profane Love Re-examined, The Art Bulletin XLVI, 1964, č. 2, s. 218-227.

Sarah Carter, „Interpretation is the revenge of the intellect upon art:“ Titian’s Sacred and Profane Love, ARTHattack! V, 2012, s. 6-26.

Ernst Cassirer, Individuum und Kosmos in der Philosophie der Renaissance, Leipzig 1927.

Ernst Cassirer - Paul Oskar Kristeller - John Herman Randall (eds.), The renaissance philosophy of man: Petrarca, Valla, Ficino, Pico, Pomponazzi, Vives, Chicago 1971 (2. vydání).

27 Ibidem, s. 367.

28 Ibidem, s. 371. 
Albrecht Dürer - Daniel Hess - Beate Böckem, The early Dürer: exhibition organized by the Germanisches Nationalmuseum, Nuremberg, May 24 - September 2, 2012, Nuremberg 2012.

Dagmar Eichberger - Charles Zika, Dürer and his Culture, New York 2005 (3. vydání).

Erazmus, Enchiridion Militis Christiani or The Manual of the Christian Knight, London 1905.

Marsilo Ficino, Three Books on Life, Binghamton 2002 (3. vydání).

Marsilio Ficino - James Hankins - Michael J. B. Allen, Platonic theology. Vol. 1, Books 1-4, Cambridge 2001.

Marsilio Ficino - Sears Reynolds Jayne, Marsilio Ficino's Commentary on Plato's Symposium: the text and a translation with an introduction, Columbia 1944.

Michael Ann Holly, Panofsky and the Foundations of Art History, Ithaca - London 1985 (2. vydání).

David Chambers, Patrons and artists in the Italian Renaissance, London 1970.

Filip Karfík, Duplex Venus. Marsilio Ficino a druhý život jednoho filosofického mýtu, in: Jana Nechutová (ed.), Druhý život antického mýtu, Brno 2004.

Ladislav Kesner, Vizuální teorie: současné anglo-americké myšlení o výtvarných dílech, Jinočany 1995.

Raymond Klibansky - Erwin Panofsky - Fritz Saxl, Saturn and Melancholy: Studies in the History of Natural Philosophy, Religion and Art, Nendeln - Liechtenstein 1979.

Paul Oskar Kristeller, The philosophy of Marsilio Ficino, Gloucester 1964.

Ulrich Kuder, Dürers „Hieronymus im Gehäus“. Der Heilige im Licht, Hamburg 2013.

Thomas Moore, Planety v nás: Astrologická psychologie Marsilia Ficina, Praha 2011.

Erwin Panofsky, Problems in Titian: mostly iconographic, New York 1969.

Erwin Panofsky, Renaissance and renascences in Western art, Boulder 1960.

Erwin Panofsky, Studies in Iconology: Humanistic Themes in the Art of the Renaissance, New York 1972.

Erwin Panofsky, The Life and Art of Albrecht Dürer, Princeton 2005.

Erwin Panofsky, Význam ve výtvarném umění, Praha 1981.

Bruno Reudenbach (ed.), Erwin Panofsky: Beiträge des Symposions Hamburg 1992, Berlin 1994.

Larry Silver - Jeffrey Chipps Smith, The Essential Dürer, Philadelphia 2010.

Stéphane Toussaint, „My Friend Ficino“: Art History And Neoplatonism From Intellectual To Material Beauty, Mitteilungen des Kunsthistorischen Institutes in Florenz LXIX, 2017, č. 2, s. 147-173. 

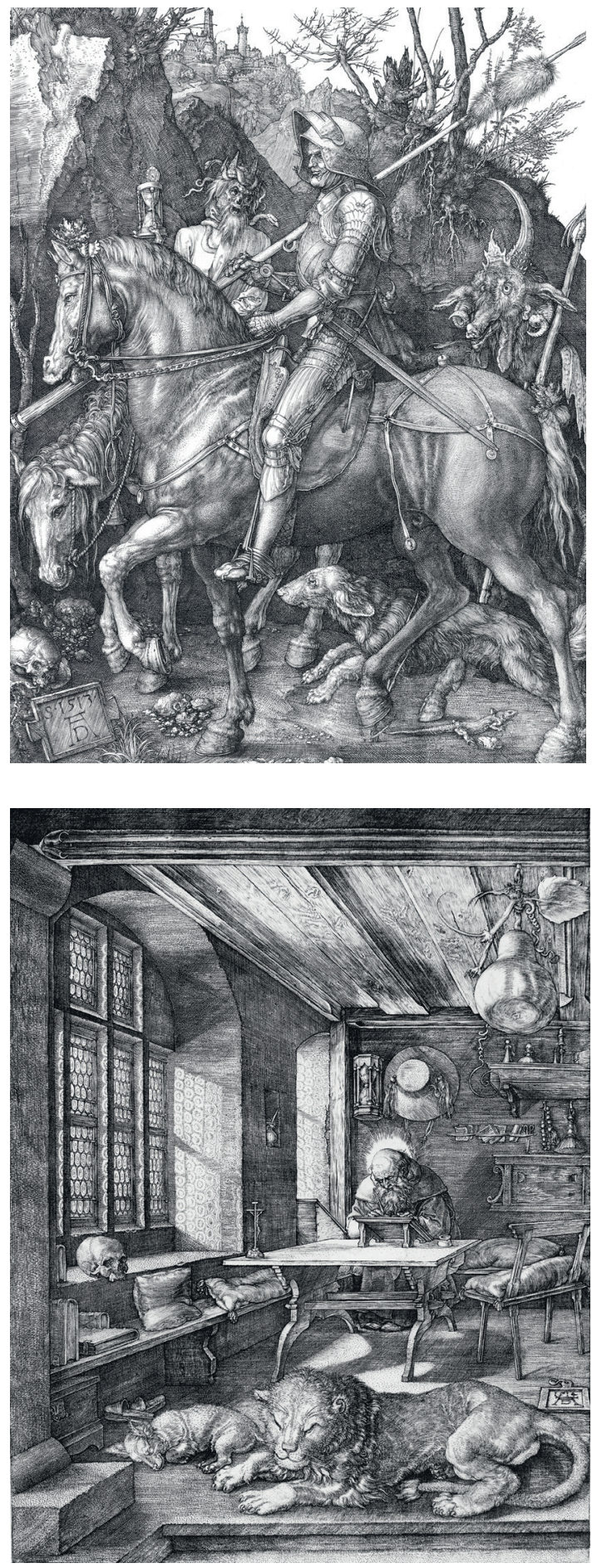

Obrázek 1: Albrecht Dürer, Rytier, smrt' a diabol, rytina, 1513. Zdroj: Wikimedia Commons, Albrecht Dürer, Knigh, Death, and the Devil
Obrázek 2: Albrecht Dürer, Hieronym vo svojej pracovni, rytina, 1514. Zdroj: Wikimedia Commons, Albrecht Dürer, Saint Jerome in his Study 


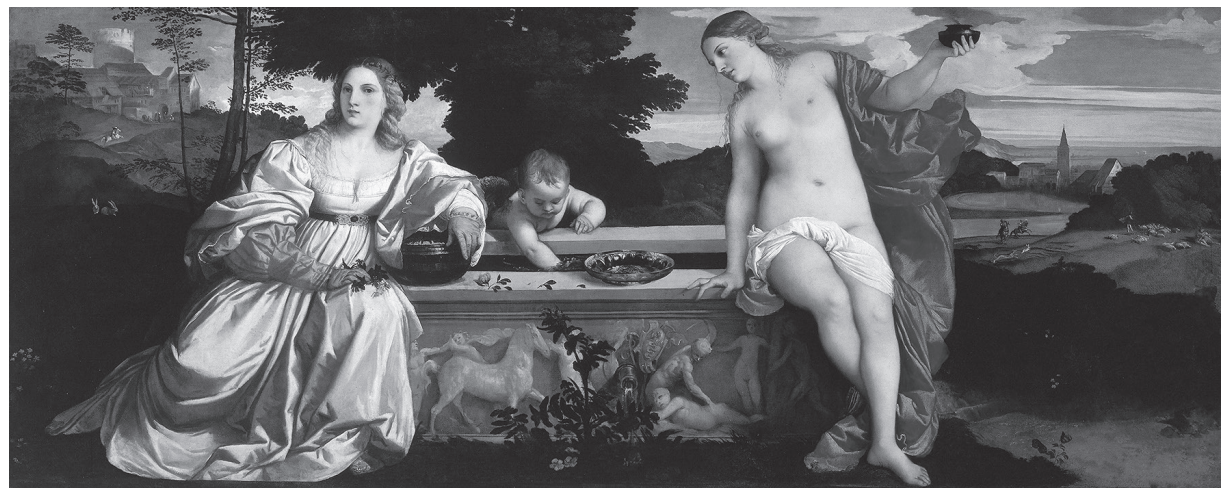

Obrázek 3: Tizian, Láska nebeská, láska pozemská, olej na plátně, 1515. Zdroj: Wikimedia Commons, Titian, Sacred and Profane Love 